\title{
Corrigendum: Xylem Sap Proteomics Reveals Distinct Differences Between $R$ Gene- and Endophyte-Mediated Resistance Against Fusarium Wilt Disease in Tomato
}

\author{
Francisco J. de Lamo ${ }^{1}$, Maria E. Constantin ${ }^{1}$, David H. Fresno ${ }^{1}$, Sjef Boeren ${ }^{2}$, \\ Martijn Rep ${ }^{1}$ and Frank L. W. Takken ${ }^{1 *}$ \\ ${ }^{1}$ Molecular Plant Pathology, Faculty of Science, Swammerdam Institute for Life Sciences, University of Amsterdam, \\ Amsterdam, Netherlands, ${ }^{2}$ Laboratory of Biochemistry, Wageningen University, Wageningen, Netherlands
}

Keywords: endophyte, biocontrol, Fusarium wilt disease, proteomics, NP24, PR-5x, exosomes

\section{A Corrigendum on}

OPEN ACCESS

Edited and reviewed by:

Alfredo Herrera-Estrella, Center for Research and Advanced Studies of the National Polytechnic Institute, Mexico

*Correspondence: Frank L. W. Takken f.l.w.takken@uva.n

Specialty section:

This article was submitted to

Plant Microbe Interactions, a section of the journal

Frontiers in Microbiology

Received: 04 July 2019

Accepted: 29 July 2019

Published: 13 August 2019

Citation:

de Lamo FJ, Constantin ME, Fresno $D H$, Boeren S, Rep M and Takken FLW (2019) Corrigendum:

Xylem Sap Proteomics Reveals Distinct Differences Between R Geneand Endophyte-Mediated Resistance Against Fusarium Wilt Disease in Tomato. Front. Microbiol. 10:1872. doi: 10.3389/fmicb.2019.01872
Xylem Sap Proteomics Reveals Distinct Differences Between $R$ Gene- and Endophyte-Mediated Resistance Against Fusarium Wilt Disease in Tomato

by de Lamo, F. J., Constantin, M. E., Fresno, D. H., Boeren, S., Rep, M., and Takken, F. L. W. (2018). Front. Microbiol. 9:2977. doi: 10.3389/fmicb.2018.02977

In the original article, there was an error. The amount of xylem sap protein used for nLCMS/MS analysis was incorrectly depicted; instead of $540 \mu \mathrm{g}$ of protein $60 \mu \mathrm{g}$ of protein was TCA precipitated and used for SDS-polyacrylamide gel electrophoresis.

A correction has been made to the MATERIALS AND METHODS section, in the sub-section Sample Preparation for nLC-MS/MS:

Potential fungal spores were removed from the sap by centrifugation at $800 \times g$ for $10 \mathrm{~min}$. Xylem sap proteins were concentrated by passing $12 \mathrm{ml}$ of cleared sap through Amicon Ultra-15 Filter Units (Millipore). After centrifugation at $2500 \times g$ for 15-30 min retentates containing the proteins were recovered. A BCA (bicinchoninic acid) assay (ThermoFischer) was performed to determine the protein concentration. Based on BCA quantification, a volume containing $60 \mu \mathrm{g}$ of protein was trichloroacetic acid/aceton-precipitated and the pellet was resuspended in SDS loading buffer ( $2 \%$ SDS, $10 \%$ glycerol, $60 \mathrm{mM}$ TRIS-HCl pH 6.8, $5 \% \beta$-mercaptoethanol, $0.01 \%$ bromophenol blue), heated at $98^{\circ} \mathrm{C}$ for $5 \mathrm{~min}$ and loaded on a $12 \%$ SDS-polyacrylamide gel. Following a short electrophoresis, the proteins were stained overnight at $4^{\circ} \mathrm{C}$ with Commassie PageBlue (ThermoFischer). The bands containing the proteins were excised and cysteine reduction and alkylation of the proteins was performed by adding $10 \mathrm{mM}$ DTT pH 8 (incubation at $60^{\circ} \mathrm{C}$ for $1 \mathrm{~h}$ ) and $20 \mathrm{mM}$ iodoacetamide $\mathrm{pH} 8$ (incubation at room temperature in the dark for $30 \mathrm{~min}$ ). Protein-containing gel slices were chopped into pieces of approximately $1 \mathrm{~mm}^{2}$ and transferred to $1.5 \mathrm{ml}$ low-binding tubes (Protein LoBind microcentrifuge tubes, Eppendorf). Tryptic in-gel digestion was performed overnight by adding $50 \mu \mathrm{l}$ of $5 \mathrm{ng} / \mu \mathrm{l}$ Trypsin Sequencing Grade (SigmaAldrich). In-house prepared $\mu$ columns were set up by adding C18 Empore disk and LichroprepC18 column material into a $200 \mu \mathrm{l}$ pipette tip and the tryptic peptides were eluted from the $\mu$ column 
with $50 \mu \mathrm{l}$ of $50 \%$ acetonitrile. Acetonitrile content was reduced to $<5 \%$ by reducing the volume with a concentrator at $45^{\circ} \mathrm{C}$ during $2 \mathrm{~h}$ and readjusting the volume with $1 \mathrm{~mL} / \mathrm{L} \mathrm{HCOOH}$ in water to $50 \mu \mathrm{l}$.

The authors apologize for this error and state that this does not change the scientific conclusions of the article in any way. The original article has been updated.
Copyright (ㅇ 2019 de Lamo, Constantin, Fresno, Boeren, Rep and Takken. This is an open-access article distributed under the terms of the Creative Commons Attribution License (CC BY). The use, distribution or reproduction in other forums is permitted, provided the original author $(s)$ and the copyright owner(s) are credited and that the original publication in this journal is cited, in accordance with accepted academic practice. No use, distribution or reproduction is permitted which does not comply with these terms. 